\title{
A Study of Glucocorticoid Receptor Gene Polymorphism (BcII) in Egyptian patients with Rheumatoid Arthritis
}

\author{
Hoda Eldeeb ${ }^{1}$, Hany Elsawy ${ }^{1,2}$ Amal El-Bendary ${ }^{3}$, Abeer Shahba ${ }^{4}$, Tarek Mostafa ${ }^{1}$, \\ ${ }^{1}$ Chemistry Department-Faculty of Science, Tanta University, Tanta, Egypt \\ ${ }^{3}$ Clinical pathology Department-Faculty of Medicine, Tanta University, Tanta, Egypt \\ ${ }^{4}$ Internal medicine Department-Faculty of Medicine, Tanta University, Tanta, Egypt
}

\begin{tabular}{|c|c|}
\hline ARTICLE INFO & ABSTRACT \\
\hline $\begin{array}{l}\text { BclI polymorphism, } \\
\text { rheumatoid arthritis, } \\
\text { genotype, glucocorticoid } \\
\text { receptor gene. }\end{array}$ & $\begin{array}{l}\text { Objective: The aim of this work was to investigate the relation } \\
\text { of the glucocorticoid receptor gene polymorphism (BclI) with } \\
\text { the rheumatoid arthritis (RA) activity. Method: This study } \\
\text { included } 20 \text { volunteers controls and } 70 \text { patients with RA ( } 35 \text { in } \\
\text { remission and } 35 \text { active). Serum } \alpha 1 \text { antitrypsin was measured } \\
\text { for all subjects by radial immunodiffusion (RID) plates. Other } \\
\text { markers of inflammation and disease activity were also } \\
\text { detected. All subjects were genotyped for glucocorticoid } \\
\text { receptor gene polymorphism using PCR-RFLP. Serum } \alpha 1 \\
\text { antitrypsin was higher in active RA patients compared to } \\
\text { inactive RA patients and controls. Results: Highly significant } \\
\text { level of } \alpha 1 \text { antitrypsin was detected with variant genotypes. } \\
\text { Significant association was found between the investigated } \\
\text { BclI polymorphism and the parameters of the RA activity. } \\
\text { Conclusions This study suggesting the relationship between } \\
\text { glucocorticoid receptor gene polymorphism and the activity of } \\
\text { RA. }\end{array}$ \\
\hline
\end{tabular}

(C) 2018 Publisher All rights reserved

\section{INTRODUCTION}

Rheumatoid arthritis (RA) happens when the immune system targets the joint linings. It is characterized by synovitis and autoantibody formation $(1,2)$. Also, RA is a systemic inflammatory disorder, meaning it affects the entire body but primarily, characterized by progressive damage of synovial joints, but is common in the wrist and fingers. More women than men get rheumatoid arthritis and its incidence rises with increasing age. (3) Glucocorticoids(GC) perform their effects through binding to their cytosolic receptor
(GR) and the formed complex translocate into the nucleus where it interacts with the promoter GC-responsive elements $(4,5)$. The control of target genes expression results from the previous interaction (6). The variability of GR gene may result from different forms of GR and in turn regulates several biological function that have an impact of the susceptibility to many diseases $(7,8)$. GR gene consists of 9 exons and 8 introns and located on chromosome 5 (locus 5931) (7). Bcl1 polymorphism consists of dialleles with 4.5 and $2.3 \mathrm{~kb}$ fragment lengths $(9,10)$. 
Many of rheumatoid arthritis patients produce a group of antibodies reactive with the Fc fragment of IgG. Alpha1antitrypsin (AAT) is a glycoprotein in blood known as a serine proteinase inhibitor. AAT inhibits a wide it variety of proteases such as proteinase 3, neutrophil elastase, and cathepsin G. Alpha1antitrypsin have anti-inflammatory, immunomodulatory, these proteases are also synthesized by monocytes (joint invading neutrophils) following inflammatory stimuli and involved in arthritis development. A lack of Alpha1antitrypsin in rheumatoid arthritis patients could increase inflammation because of uninhibited lysosomal enzymes leads to a chronic uninhibited tissue breakdown (11).

In this study, we aimed to find the association of glucocorticoid receptor gene variation with the risk of RA and its activity, serum $\alpha 1$ antitrypsin level and different rheumatoid inflammatory markers.

\section{Patients and Methods Study population}

In this study three groups of patients was studied group I: 20 healthy volunteers serving as control group, a total of 70 RA patients were enrolled in this study, two groups were defined as follows: 35 of them were in remission (inactive group II) and the other 35 were in the active form of the disease (active group III). American Rheumatism Association (ARA) purposed a diagnostic criteria for RA (12), and the clinical activity was assessed according to the 28 count Disease Activity Score (DAS28).It was calculated with the following equation: DAS28 $=0.56 \times$ $\sqrt{2} 8 \mathrm{TJC}+0.28 \times \sqrt{2} 8 \mathrm{SJC}+0.7 \times \mathrm{In} \mathrm{ESR}$ $+0.014 \times \mathrm{GH}$, where 28SJC and 28TJC are the swollen joint count and tender joint count from 28 joints and general health $(\mathrm{GH})$ is the patient's global assessment on a 100-mm visual analog scale (VAS) (13). The included subjects were randomly chosen from Internal Medicine Department of Tanta University Hospital, Egypt during the period from May2014 to April 2015.

\section{Sampling}

Peripheral blood was drawn from each volunteer, and was divided into 2 portions: $1 \mathrm{ml}$ of whole blood was collected into evacuated tubes containing EDTA for DNA extraction, and the remaining portion of the blood was used to separate serum immediately. Separated serum was stored at $-20{ }^{\circ} \mathrm{C}$ until further use.

\section{Determination of serum rheumatoid inflammatory parameters}

Rheumatoid factor (RF) was measured by a quantitative immunonephelometry (Behring, Marburg, Germany). C-reactive protein (CRP) was measured by semiquantitative latex test (Omega, Avitex, UK). The erythrocyte sedimentation rate (ESR) was measured by the Westergren method; the reading of the 1 st hour was included in the study (14). $\alpha 1$ - antitrypsin concentration in serum was assayed by radial immunodiffusion using commercial assay Kit. $\alpha 1-$ antitrypsin was obtained from KALLESTAD (15).

\section{DNA extraction and genotyping}

DNA was isolated and from whole blood according to the manufacturer instructions (Gene JET Genomic DNA) Purification Kit; Thermo Scientific, EU Lithuania). Isolated DNA was stored at $-20{ }^{\circ} \mathrm{C}$ until use. polymorphism was detected using the polymerase chain reaction -restriction fragment length polymorphism method (PCR-RFLP). The following primers were used: forward primer (5'dTAA GCC CAG ACC TGC TGT TG3'). and reverse primer 5'-(5'dGGG GTT TAC ACA ACC CGC TA3').

The PCR reaction was carried out in a total volume of $50 \mu \mathrm{l}$ containg $50 \mathrm{ng}$ of genomic DNA, $0.5 \mu \mathrm{M}$ each primer (Biosearch Technologies, Petaluma,Ca USA) , $100 \mu \mathrm{M}$ dNTPs, 10 mMTris- $\mathrm{HCl}$ (pH 8.3), $1.5 \mathrm{mM} \mathrm{MgCl}_{2}, 50 \mathrm{mMKCl}$ and 
$0.5 \mathrm{U}$ of Taqpolymerase. The amplification cycle was performed as follows: firstly, denaturation at $95{ }^{\circ} \mathrm{C}$ for 7 min, preannealing at $64{ }^{\circ} \mathrm{C}$ for $1 \mathrm{~min}$, and then elongation at $72{ }^{\circ} \mathrm{C}$ for $2 \mathrm{~min}$ followed by 35 cycles of $30 \mathrm{~s}$ at $95^{\circ} \mathrm{C}, 30$ $\mathrm{s}$ at $64^{\circ} \mathrm{C}$ and $1 \mathrm{~min} 15 \mathrm{~s}$ at $72{ }^{\circ} \mathrm{C}$, and finally, elongation at $72{ }^{\circ} \mathrm{C}$ for $10 \mathrm{~min}$. To investigate the Bcll polymorphism, $10 \mu \mathrm{l}$ of the PCR products was digested with $4 \mathrm{U}$ of restriction endonuclease $\mathrm{Bcll}$ (New England Biolabs Ltd, UK) for $6 \mathrm{~h}$ at $50^{\circ} \mathrm{C}$ and the digested products were separated on $1 \%$ agarose gel in TBE buffer. The gel was stained with ethidium bromide and observed in UV-light. Digestion of the PCR product might give the following predicted fragment sizes: two bands of 90 and 116bp in the case of homozygous individual for the shorter allele (G/G); a single band of $206 \mathrm{bp}$ for homozygous individual for larger allele $(\mathrm{C} / \mathrm{C})$ and three bands of 90, 116, and $206 \mathrm{bp}$ for heterozygous individuals $(\mathrm{G} / \mathrm{C})$ (Table 5) (16).

\section{Statistical analysis}

The results for quantitative variables were analyzed using one-way ANOVA tests and were expressed as the mean \pm SD. Qualitative variables were expressed as percentages and were compared using the Chi-square test. A value of $\mathrm{P}<0.05$ was considered statistically significant. All data were evaluated using the statistical package for social sciences (SPSS).

\section{Results and Discussion}

Our study aim to identify the common genotype of GR gene Bcl1 polymorphism in some Egyptian RA patients using Polymerase chain reaction-restriction fragment length polymorphism (PCRRFLP) and measuring clinical diagnostic parameters the erythrocyte sedimentation rate (ESR), alantitrypsin, C-reactive protein (CRP) and rheumatoid factor (RF), $\alpha$ lantitrypsin.

In this study, the 3 included groups (healthy controls, active RA and inactive RA) were homogenous as regards age, sex. levels of serum ESR and CRP were significantly higher in the active RA group compared to both inactive RA and control groups. RA patients had significantly higher levels of RF and DAS28 score rather than inactive patients. Alpha-1 antitrypsin significantly higher in the active and inactive RA groups compared to control groups. Also, There was no significant difference between both patient groups as regards Alpha-1 antitrypsin. (Table 1)

There were no significant differences between the genotypes as regards age, Levels of ESR, CRP,RF, DAS28 and alpha 1 antitrypsin were significantly increased in GG genotypes compared to $\mathrm{CC}$ genotypes. (Tabl 2). There were no significant differences between the genotypes as regards RF,ESR,CRP and DAS28 in active RA patients. (Table 4)

Polymorphism of Glucocorticoid Receptor (GR) gene, resulting from variability of $G R$ gene, can affect many biological functions regulation, such as GC responsiveness and regulation of hypothalamic-pituitary-adrenal axis, thereby underlying susceptibility to many diseases. The BclI site was found to be in either the first or second intron of the GR gene (17). There are three Bcll sites, one in intron 1 and two in intron 2. Only the site within intron 2 has Bcllpolymorphism where at $647 \mathrm{bp}$ from exon/intron junction (18). In case of presence of wild type restriction site of Bcll (TGATCA), fragments of $2.2 \mathrm{~kb}$ will be generated after enzymatic digestion. On the other hand, fragments of $3.9 \mathrm{~kb}$ will be produced in case of polymorphic Bcl1 site (TCATCA), where the bold base indicated the $\mathrm{G} / \mathrm{C}$ transition. Our primers were designed to flank the Bcl1 site at position +647 , giving a fragment of $206 \mathrm{bp}$. To study the Bcl1 polymorphism among our patients, the DNA product was digested with $\mathrm{Bcll}$ restriction endonuclease and the genotype 
was determined according to the pattern of digested fragments (see Table 5).

Alpha1-antitrypsin is a very effective inhibitor of proteolytic enzyme, responsible for almost $90 \%$ of the total serum trypsin inhibitory capacity. Increased inflammation and activity of lysosomal enzyme in rheumatoid arthritis may force the concentration of alpha1antitrypsin to rise (11).

This study showed there was no significant difference between both active and inactive patient groups as regards Alpha-1 antitrypsin which were significantly increased in GG genotypes compared to $\mathrm{CC}$ genotypes.

Brackertz et al., compared the levels of proteinase inhibitors between normal individuals and patients of probable and classical rheumatoid arthritis and found out that there was a significant rise in the levels of alpha1-antitrypsin inhibitor in serum as well as in synovial fluid of rheumatoid arthritis patients (19). The immunochemically determined levels of alpha-1-antitrypsin were found to be raised in the patients but their proteinase inhibitory capacity was depressed. This implied to the fact that, though the alpha1antitrypsin levels were raised in the rheumatoid arthritis patients, they were partially inactivated with a decreased specific elastase inhibitory activity (20). In another study, the quantitative radial immuno diffusion method was used to study the concentration of alpha1antitrypsin in the serum and synovial fluid. The levels were much higher in the rheumatoid arthritis patients than the healthy controls idviduals (21).

On the contrary, other studies reported that the minor alleles of the BclI and N363 S polymorphisms are associated with decreased susceptibility to RA development. These opposite associations suggest that determined GC resistance may predispose to development of autoimmune disorders, at least in RA, and vice versa (22).

\section{Conclusions}

Glucocorticoid receptor gene is important for RA and could use as clinical manegment of RA. Further studies on large individuals groups may cause more association between gene polymorphism and RA patient degree.

\section{References}

1- Krysiak, R., Handzlik-Orlik, G., and Okopien, B. 2012. The role of adipokines in connective tissue diseases. Eur.J.Nutr.,51:513-528.

2- Klein-Wieringa, I.R., van derLinden, M.P.M., Knevel, R., Kwekkeboom, J.C., van Beelen, E., Huizinga, T.W.J., van der Helm-van Mil, A., Kloppenburg, M., Toes, R. E. M., and Ioan-Facsinay, A. 2011. Baseline Serum adipokine levels predict radiographicprogression in early rheumatoid arthritis. Arthritis Rheum. 63(9): 25672574.

3- Manole,C., Minerva, G.C., Constantin, B., Mihaela, C.I. and Isabela, S. 2011. Prevalence of Antibodies to CReactive Protein and Correlation with Disease Activity in Patients with Rheumatoid Arthritistoid Arthritis. Med. Con. 6(4): 2730.

4- Schimmer, B.P. and Parker, K.L. 1996.

Adrenocorticotropic hormone; adrenocortical steroids and their synthetic analogs. In: Hardmam JG, Limbird LE, Gilman AG, eds. The pharmacological basis of 
therapeutics. New York: McGraw-Hill, 1649-1678.

5- Weikum, E. R. Knuesel, M. T., Ortlund, E. A. and Yamamoto, K. R. 2017. Glucocorticoid receptor control of transcription: precision and plasticity via allostery. Nature Reviews Molecular Cell Biology18,159-174.

6- Tait, A.S. Butts,C.L. and Sternberg, E.M. 2008. The role of glucocorticoids and progestins in inflammatory, autoimmune, and infectious disease. J. Leukoc. Biol. 84(4): 924-931.

7- Derijk, R.H., Schaaf, M. and de Kloet, E.R. 2002.Glucocorticoid receptor variants: clinical implications. J Steroid BiochemMol Biol. 81; 103-122.

8- Panek, M. Pietras,T. Fabijan, A. Milanowski,M. Wieteska, L. Gorski, P. Kuna, P. and Szemraj, J. 2013. Effect of glucocorticoid receptor gene polymorphisms on asthma phenotypes. ExpTher Med 5(2): 572-580.

9- Murry, J.C,, Smith, R.F., Ardinger, H.A. and Weinberger, C. 1987. RELP for the glucocorticoid receptor (GRL) located at 5q11-5q13, Nucleic Acids Res. 15; 6765.

10-Lobodzińska, A. M. and Mroczek, J. A. 2017. Glucocorticoid receptor polymorphism in obesity and glucose homeostasis. Adv Clin Exp Med.;26(1):143-148
11-Salman, K. A., Ahsan, A. and Ashraf, S. 2014. Alpha 1antitrypsin and Its Involvement In Rheumatoid Arthritis. 22 (2) : 180-184.

12- Arnett, F.C., Edworthy, S.M., Bloch, D.A., Mcshane, D.J., Fries, J.F., Cooper, N.S., Healey, L.A., Kaplan, S.R., Liang, M.H. Luthra, H.S., Medsger, T.A., Mitchell, D.M., Neustadt, D.H., Pinals, R.S., Schaller, J.G., Sharp, J.T., Wilder, R.L. and Hunder, G.G. 1988. The American Rheumatism Association 1987 revised criteria for the classification of rheumatoid arthritis. Arthritis Rheum.,31: 315-324.

13- Fransen, J., and van Riel, P. L. 2005. The Disease Activity Score and the EULAR response criteria. Clin. Exp. Rheumatol.,23: S93-S99.

14- Westrgren, A. 1975. Diagnostic tests: the erythrocyte sedimentation rate range and limitations of the technique. Triangle. 3(1): 2025.

15- Mancini, M., Carbonara, A.O. and Heremans, J.F.1965. Immunochemical quantitation of antigens by single radial immunodiffusion. Immunochemistry $2: 235-254$.

16- Tang, N.P., Wang, L.S., Yang, L., Zhou, B., Gu, H. J., Sun Q. M., Cong R. H., Zhu, H. J. and Wang, B. 2007. A polymorphism in the resistin gene promoter is related to increased C-reactive protein levels in patients with coronary artery disease. Clin. 
Chem.Lab.Med.,45(11): 14711475.

17- Fleury, I., Beaulieu, P., Primeau, M., Labuda, D., Sinnett, D. and Krajinovic, M. 2003. Characterization of the Bcl1 polymorphism in the glucocorticoid receptor gene. Clin Chem. 49; 1528- 1531.

18- Srivastava, N., Prakash, J., Lakhan, R., Agarwal, C.G., Pant, D.C. and Mittal, B. 2011. Influence of Bcl-1 Gene Polymorphism of Glucocorticoid Receptor (NR3C1, rs41423247) on Blood Pressure, Glucose in Northern Indians. Indian $J$ ClinBiochem. 26 (2);125-30.

19- Brackertz, D.; Hagmann, J.; and Kueppers, F.(1975): Proteinase inhibitors in rheumatoid arthritis. Ann. Rheum. Dis. 34: 225-230.

20- Moreland, L.W., Baumgartner, S.W., Schiff, M.H., Tindall, E.A., Fleischmann, R.M., Weaver, A.L., Ettlinger, R.E, Cohen, S., Koopman, W.J., Mohler, K., Widmer, M.B. and Blosch, C.M. 1997. Treatment of rheumatoid arthritis with a recombinant human tumor necrosis factor receptor (p75)Fc fusion protein. New Eng $J$ Med. 337(3): 141-147.

21- Swedlund, H.A., Hunder, G.G. and Gleich, G.J. 1974. Alpha 1 antitrypsin in serum and synovial fluid in rheumatoid arthritis. Annuals of the Rheumatic Diseases 33: 162165.

22- Oosten, M.V.; Dolhain R. J. E. M. ; Koper, J. W. and Feelders, R. A. 2010. Polymorphisms in the glucocorticoid receptor gene that modulate glucocorticoid sensitivity are associated with rheumatoid arthritis. Arthritis Res Ther. 12(4): R159. 
Table.1 Clinical and biochemical characteristics of RA patients and healthy control

\begin{tabular}{|c|c|c|c|c|c|c|}
\hline Parameters & $\begin{array}{c}\text { Healthy } \\
\text { Controls } \\
\text { (group I) n= } \\
\mathbf{2 0}\end{array}$ & $\begin{array}{c}\text { Inactive RA } \\
\text { cases } \\
\text { (group II) n= } \\
\mathbf{3 5}\end{array}$ & $\begin{array}{c}\text { Active RA } \\
\text { cases } \\
\text { (group III) n = }\end{array}$ & P1 & P2 & P3 \\
\hline Age & $42.03 \pm 8.77$ & $43.03 \pm 10.48$ & $44.46 \pm 9.94$ & 0.666 & 0.282 & 0.560 \\
\hline Sex M/F & $5 / 15$ & $5 / 30$ & $7 / 28$ & 0.322 & 0.666 & 0.526 \\
\hline DAS & & $1.78 \pm 0.51$ & $4.71 \pm 1.02$ & & & $0.001 *$ \\
\hline CRP & $3.38 \pm 1.2$ & $4.86 \pm 2.83$ & $48.29 \pm 26.08$ & $0.031 *$ & $0.001 *$ & $0.001 *$ \\
\hline RF & & $26.89 \pm 15.77$ & $105.91 \pm 37.68$ & & & $0.001 *$ \\
\hline ESR & $12.13 \pm 2.49$ & $16.46 \pm 9.68$ & $78.51 \pm 18.11$ & 0.056 & $0.001 *$ & $0.001 *$ \\
\hline Alpha-1 & $149.7 \pm 52.6$ & $209.4 \pm 35.13$ & $247.1 \pm 54.45$ & $0.010^{*}$ & $0.001 *$ & 0.092 \\
antitrypsin & & & & & & \\
\hline
\end{tabular}

Table.2 Relation between BclI polymorphism and the clinical and biochemical characteristics of all RA patients $(n=70)$

\begin{tabular}{|c|c|c|c|c|c|c|}
\hline Parameters & $\begin{array}{c}\text { Healthy } \\
\text { Controls } \\
\text { (group I) n } \\
=\mathbf{2 0}\end{array}$ & $\begin{array}{c}\text { CC V } \\
(\mathbf{n = 2 2})\end{array}$ & $\begin{array}{c}\text { GG IV } \\
(\mathbf{n = 4 8})\end{array}$ & P1 & P2 & P3 \\
\hline Age & $42.03 \pm 8.77$ & $41.05 \pm 10.91$ & $43.88 \pm 9.82$ & 0.752 & 0.468 & 0.284 \\
\hline Sex M/F & $5 / 15$ & $2 / 20$ & $8 / 40$ & 0.167 & 0.426 & 0.401 \\
\hline DAS & & $1.82 \pm 0.53$ & $3.89 \pm 1.63$ & & & $0.001^{*}$ \\
\hline CRP & $3.38 \pm 1.2$ & $5.18 \pm 2.99$ & $36.40 \pm 29.71$ & $0.016^{*}$ & $0.001^{*}$ & $0.001^{*}$ \\
\hline RF & $12.13 \pm 2.49$ & $35.05 \pm 32.21$ & $63.31 \pm 31.0$ & $0.003 *$ & $0.001^{*}$ & $0.001^{*}$ \\
\hline ESR & $149.7 \pm 52.6$ & $275.6 \pm 65.6$ & $221.31 \pm 55.4$ & $0.001^{*}$ & $0.010^{*}$ & $0.046^{*}$ \\
\hline $\begin{array}{c}\text { Alpha-1 } \\
\text { antitrypsin }\end{array}$ & & & & & & \\
\hline
\end{tabular}


Table.3 Frequencies of BclI genotypes in RA patients and healthy controls

\begin{tabular}{|c|c|c|c|c|c|}
\hline & & & $\begin{array}{l}\text { Inactive RA cases } \\
\text { (group II) } \mathbf{n}=35\end{array}$ & $\begin{array}{c}\text { Active RA cases } \\
\text { (group III) } n= \\
35\end{array}$ & Total \\
\hline \multirow{2}{*}{\multicolumn{2}{|c|}{$\mathrm{CC}$}} & $\mathbf{N}$ & 32 & 7 & 39 \\
\hline & & $\%$ & $91.0 \%$ & $20.0 \%$ & $21.4 \%$ \\
\hline \multirow{2}{*}{\multicolumn{2}{|c|}{ GG }} & $\mathbf{N}$ & 3 & 28 & 31 \\
\hline & & $\%$ & $9.0 \%$ & $80.0 \%$ & $78.6 \%$ \\
\hline \multirow{2}{*}{$\begin{array}{l}\text { Chi- } \\
\text { square }\end{array}$} & $\mathbf{X}^{2}$ & \multicolumn{4}{|c|}{36.192} \\
\hline & $\begin{array}{c}\text { P- } \\
\text { value }\end{array}$ & \multicolumn{4}{|c|}{$0.001 *$} \\
\hline
\end{tabular}

Table.4 Relation between Bcl1 polymorphism and the parameters of the disease activity in active $R A$ patients $(n=35)$

\begin{tabular}{|c|c|c|c|}
\hline Parameters & VI-GG $(\mathbf{n}=25)$ & VII-CC $(\mathbf{n}=10)$ & p. value \\
\hline Age & $44.0 \pm 10.61$ & $45.60 \pm 8.44$ & 0.674 \\
\hline Sex M/F & $6 / 19$ & $1 / 9$ & 0.350 \\
\hline DAS & $4.81 \pm 1.04$ & $4.44 \pm 0.96$ & 0.336 \\
\hline CRP & $49.76 \pm 26.55$ & $44.60 \pm 25.85$ & 0.604 \\
\hline RF & $99.56 \pm 20.61$ & $121.80 \pm 61.96$ & 0.116 \\
\hline ESR & $80.40 \pm 18.72$ & $73.80 \pm 16.44$ & 0.338 \\
\hline
\end{tabular}




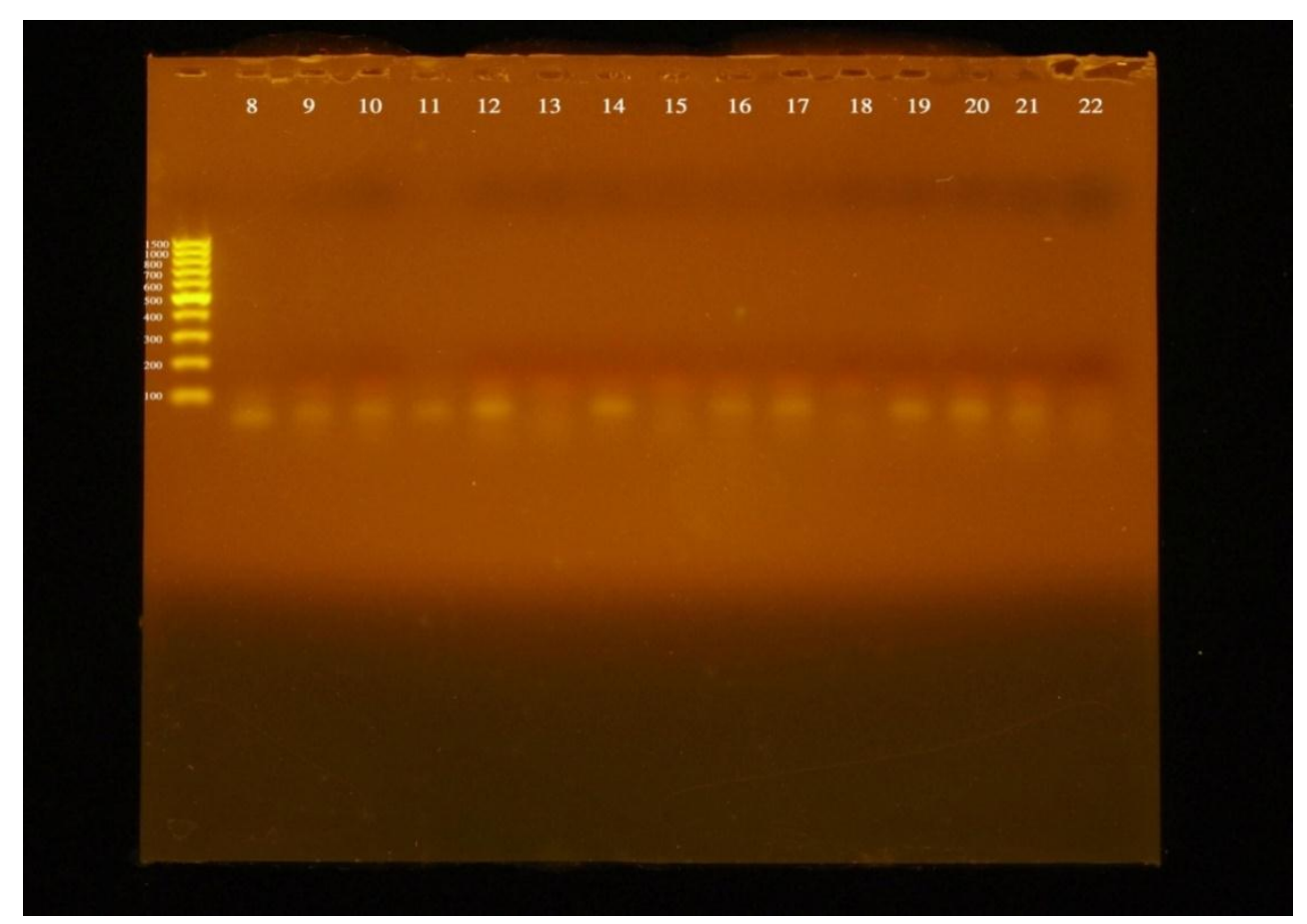

Fig.(1):Agarose gel Electrophoresis of Bcl1 gene polymorphism.Lane 1: DNA ladder;lane 8 healthy control, lanes 9-22: PCR product digestion of 15 patients. The digestion pattern shows a homozygous individual for the smaller allele. The digestion of PCR product by the Bcll enzyme produced two fragments for homozygous $\mathrm{G} / \mathrm{G}$.

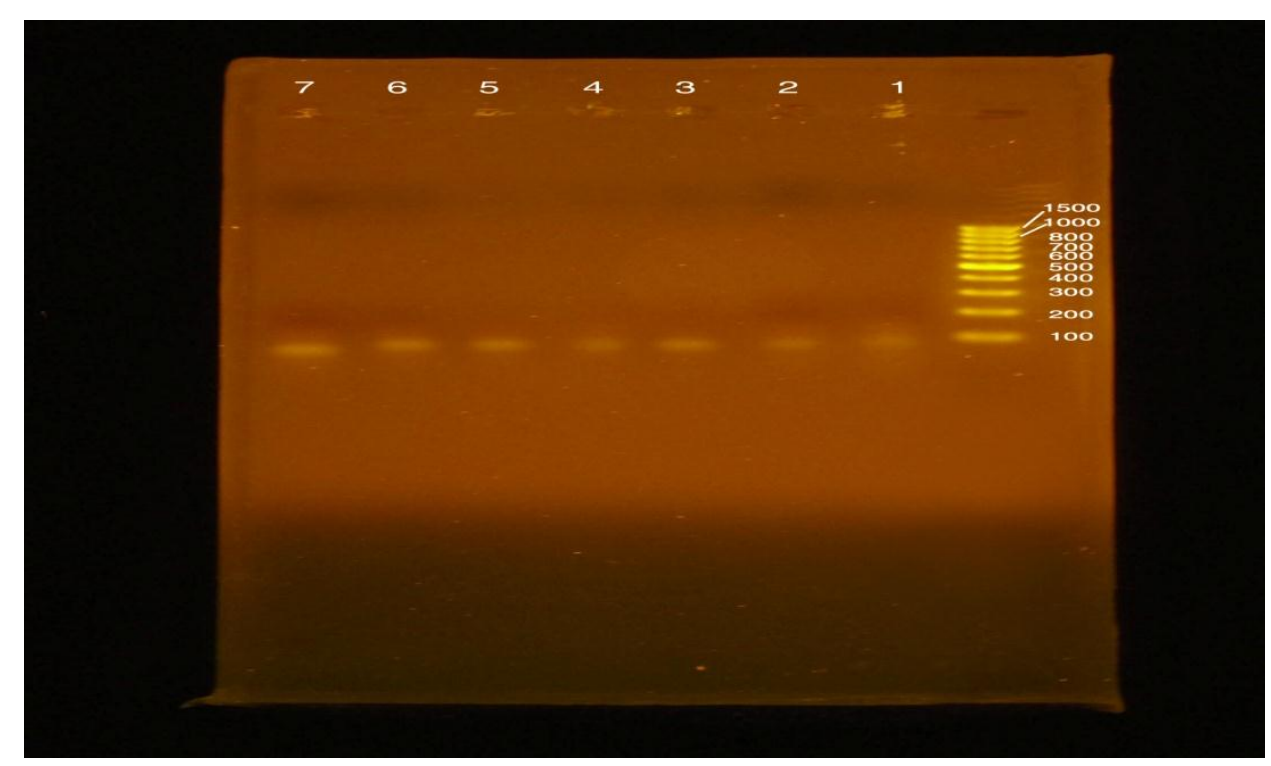

Fig.(2):Agarose gel Electrophoresis of Bcl1 gene polymorphism.Lane 1: DNA ladder;lane 1 healthy control, lanes 2-7: PCR product digestion of 15 patients. The digestion pattern shows a homozygous individual for the larger allele. The digestion of PCR product by the Bcll enzyme produced two fragments for homozygous $\mathrm{c} / \mathrm{c}$. 
A-

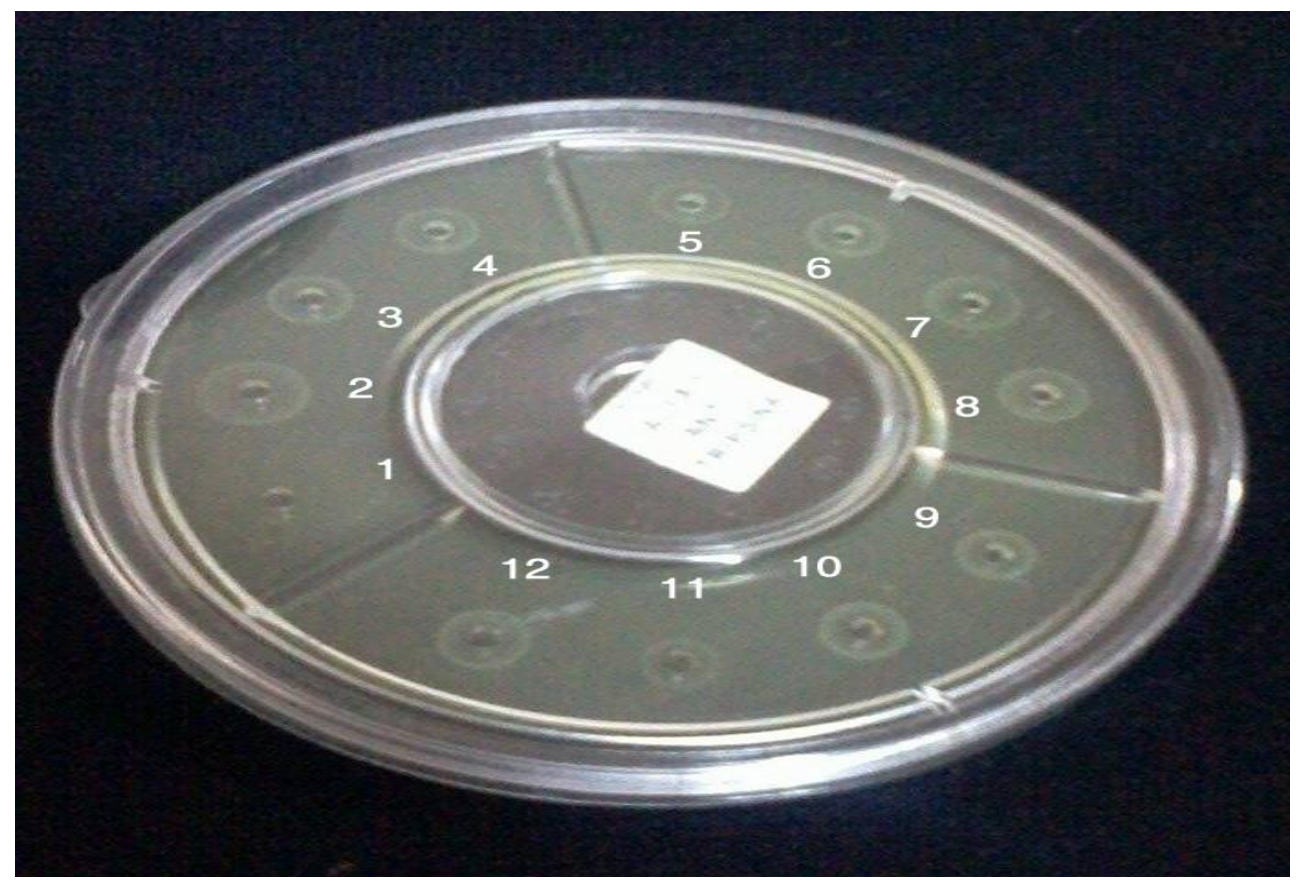

B-

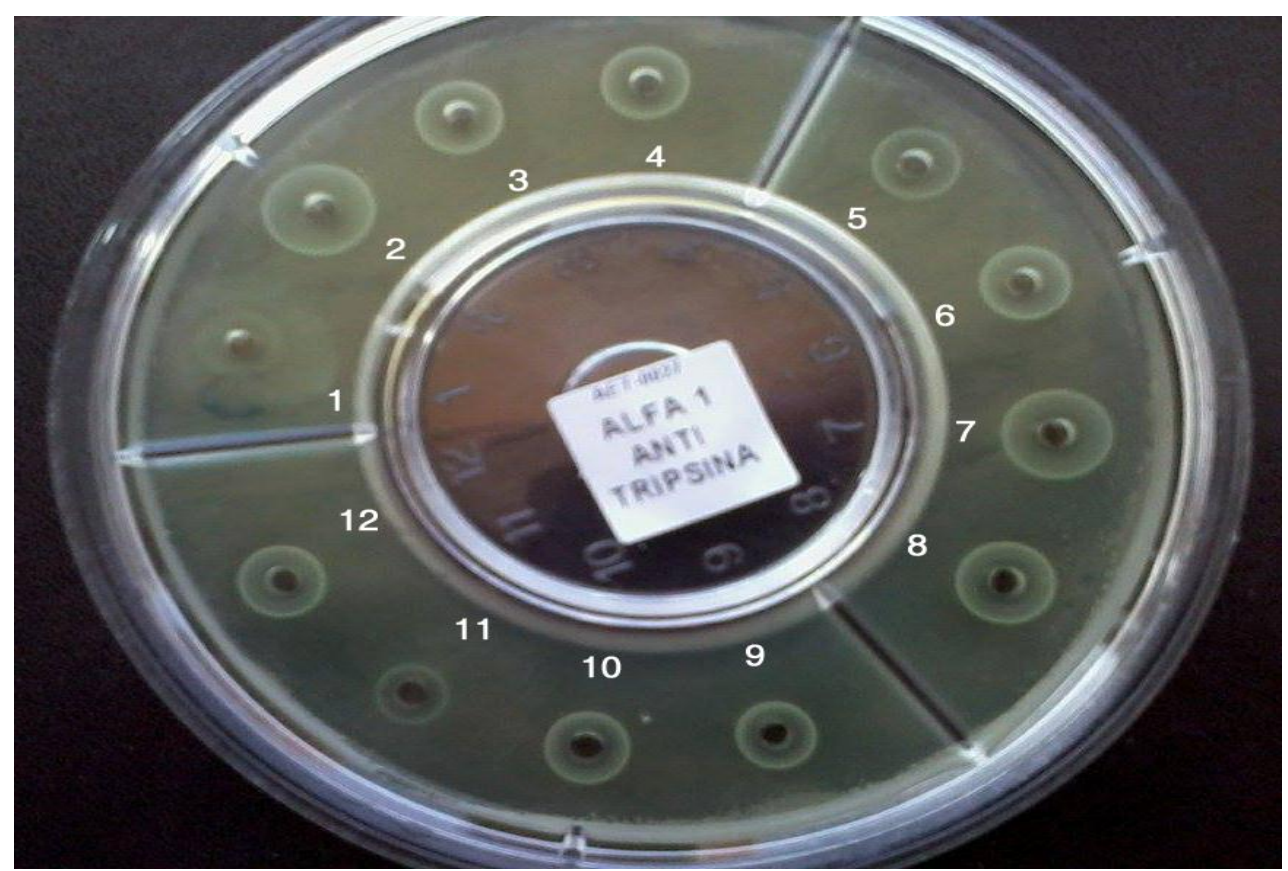

Fig. (3 ): Photogram showing the immunoprecipitation ring of serum $\alpha 1$ antitrypsin in RA patients, well 1 healthy control. Photo A, B. 